http://dx.doi.org/10.32929/2446-8355.2020v29n2p143-156

\title{
STABILITY AND ADAPTABILITY IN ASSAI PALM TREE PROGENIES BY GGE BIPLOT
}

Gilberto Ken Iti Yokomizo ${ }^{1 *}$, Kuang Hongyu ${ }^{2}$, João Tomé de Farias Neto ${ }^{3}$, Maria do Socorro Padilha de Oliveira ${ }^{4}$

\footnotetext{
${ }^{1 *}$ Pesquisador, Doutor, Genética e Melhoramento de Plantas, Embrapa Amapá, Macapá, AP, Brasil. *E-mail do autor correspondente: gilberto.yokomizo@embrapa.br

${ }^{2}$ Docente, Doutor, Estatística e Experimentação Agronômica, Universidade Federal do Mato Grosso, Cuiabá, MT, Brasil.

${ }^{3}$ Pesquisador, Doutor, Genética e Melhoramento de Plantas, Embrapa Amazônia Oriental, Belém, PA, Brasil.

${ }^{4}$ Pesquisadora, Doutora, Genética e Melhoramento de Plantas, Embrapa Amazônia Oriental, Belém, PA, Brasil.
}

Recebido: 29/10/2018; Aceito: 02/03/2020

\begin{abstract}
The increasing demand for the fruit of the assai palm has generated the need for research to enable higher productivity. A GGE biplot was used to analyze the behavior of 30 assai palm tree genotypes from Anajás city and grown in Tomé-Açu, Pará, in a randomized complete block design, with 30 treatments (progenies G1 until G30), three replicates and five plants per plot in four years (A1 until A4). The following characteristics were evaluated: total weight of bunches (PTC), in grams; total weight of fruit (PTF), in grams; and average weight of 100 fruit (PCF). Obtaining as conclusions that the progenies G10 for PTC and PTF; G19 for large fruits or G25 for "chumbinho" fruits for PCF are closest to the ideotype, with better average performance and also in terms of stability and adaptability; most progenies with higher averages have poor stability in PTC and PTF, differently for PCF whose progenies were very close averages and concentrated in terms of stability; the GGE biplots allow us to visualize of the progenies behavior, of the years, of the interrelationship between progenies and years and identify the superior progenies. By graphical analysis of GGE Biplot the environments contribute more intensely to the interaction $\mathrm{G} \times \mathrm{E}$ in relation to the progenies, highlighting A3 for PTC; A2 for PTF and; A4 to PCF. The years A1 and A2 for PTC; A1 for PTF and; A2 for PCF represent the average from all years.
\end{abstract}

Key words: Euterpe oleracea. G x E Interaction. Plant breeding. Parental selection.

\section{ESTABILIDADE E ADAPTABILIDADE EM PROGÊNIES DE AÇAIZEIRO PELO GGE BIPLOT}

RESUMO: O aumento da demanda de frutos de açaizeiro gera a necessidade de pesquisas para viabilizar maior produtividade. O GGE Biplot foi utilizado para analisar o comportamento de 30 genótipos de açaizeiros (progênies G1 a G30) provenientes do município de Anajás e cultivadas em Tomé-Açu, Pará, em delineamento experimental de blocos casualizados, com trinta tratamentos (progênies), três repetições e cinco plantas por parcela em quatro anos (A1 até A4), foram avaliadas as características: peso total de cachos (PTC), em gramas; peso total de frutos (PTF), em gramas; peso médio de 100 frutos (PCF), 
em gramas. Obtendo-se como conclusões que as progênies G10 para PTC e PTF; G19 para frutos grandes ou G25 para frutos chumbinho para PCF são as que mais se aproximam do ideótipo, com melhor desempenho médio e também em termos de estabilidade e adaptabilidade; a maioria das progênies com médias superiores apresentam baixa estabilidade em PTC e PTF, diferentemente para PCF cujas progênies se apresentaram com médias muito próximas e concentradas em termos de estabilidade; os GGE biplot permitem visualizar o comportamento das progênies, dos anos, o inter-relacionamento entre progênies e anos e identificar as progênies superiores. Pela análise gráfica dos GGE Biplot os ambientes contribuem em maior intensidade para a interação $\mathrm{G} x \mathrm{E}$ em relação às progênies, destacando A3 para PTC; A2 para PTF e; A4 para PCF. Os anos A1 e A2 para PTC; A1 para PTF e; A2 para PCF representam a média de todos os anos.

Palavras-chave: Euterpe oleracea. Interação G x E. Melhoramento de plantas. Seleção de parentais.

\section{INTRODUCTION}

The assai palm (Euterpe oleracea) is important for providing fruit for the consumption of its pulp and of the palm heart. It is an endemic species from the Amazon, and it has been traditionally exploited by extracting from natural habitats. The State of Pará has the largest production and domestic consumption, containing dense and diversified natural populations present in areas of floodplains. In the last estimate published by IBGE (2016), the harvest of 2015 reached a total of 215,609 tons, raising $R \$ 539.8$ million. The Brazilian extractive production is mainly concentrated in the Northern Region, which holds $91.9 \%$ of the national production. The State of Pará stands out as the largest national producer, producing $61.2 \%$ of the national output and production of 131,836 tons from extractive assai fruit, followed by the Amazon, with $26.7 \%$. Others states considered important in the production of assai are Maranhão, Acre, Amapá, Rondônia and Roraima.

The increasing consumption from new markets located in different regions, both within the country and internationally, generated new market dynamics of the assai fruits. The extraction and management of assai palms in floodplains did not produce enough to meet the demand, leading to the process of cultivation of the assai palm on uplands. This production system has evolved in the state of Pará, where cultivation is practiced according to technical recommendations for spacing, fertilization, irrigation and selected plants (NOGUEIRA et al., 2013). The adoption of new technologies in the system of producing assai palms, especially in the management and breeding of genetically superior plants, reflects an increase in productivity of the fruit, which has contributed to the improvement of the socioeconomic benefit of the entire productive chain (NOGUEIRA; SANTANA, 2016).

For genetic improvement, the existence of genetic variability and divergence is needed to obtain the information necessary to aid the selection process (GOMES JÚNIOR et al., 2014). Published studies demonstrate the existence of genetic differences between populations and/or progenies of assai progenies, with the presence of different genotypes featuring 
prominence. This fact opens the possibility to select for superior genetics materials to desired characteristics (YOKOMIZO et al., 2016a, b; FARIAS NETO et al., 2018).

The environment in which genetic material is grown affects its phenotypic expression. Therefore, the more variation in environmental factors, the greater the likelihood of the presence of variation in the expression of vegetative and reproductive traits in plants. This phenomenon is known as the genotype versus environment $(\mathrm{GxE})$ interaction and is a complicating factor in the work of improvement (TEODORO et al., 2015; MORETO et al., 2017), as it reduces the correlation between phenotypic and genotypic values, making it harder to select and recommend adaptive and stable genotypes (CRUZ et al., 2014).

For the evaluation of adaptability and stability, among the more recent methodologies the GGE biplotmodel, proposed by Yan et al. (2000), has been highlighted.It considers the main effect of genotype more than the GxE interaction, and is usedfor the identification of mega-environments, selection of representative environments and discriminating and indicating genotypes better adapted and stable inspecific environments (GAUCH et al., 2008; YAN, 2011). It does this by making inferences regarding the performance of genetic materials and environments allowing the visualization of behavior in an easier way (YAN et al., 2000, 2002; HASSANPANAH, 2010).

Based on this information, the objective of this work was to evaluate agronomic performance of progenies of assai palms from the municipality of Anajás, Pará, cultivated in the experimental area in Tomé-Açu, Pará, aiming to identify, through GGE Biplot, the more responsive progenies associated with levels of environmental variation and genotypes capable of expressing predictable behavior despite different environmental factors.

\section{MATERIAL AND METHODS}

The study was conducted in the Embrapa Amazonia Oriental experimental baselocated in the municipality of Tomé-Açu River in northeastern Pará (acronym PA), approximately between latitudes $01^{\circ} 24^{\prime} 46.14^{\prime \prime}$ and $01^{\circ} 28^{\prime} 4.11^{\prime \prime}$ South latitude and $48^{\circ} 20^{\prime} 4.60^{\prime \prime}$ and $48^{\circ}$ $20^{\prime} 31.84 "$ West longitude. This region has a hot and humid climate, adjusting to the AMI climatic type according to the Köppen classification (BRASIL, 1984). It is characterized as wet, but with a small dry season, and is characterized by two distinct precipitation periods; one is fromDecember to May, with rainfall exceeding $150 \mathrm{~mm}$ per month, and the other is fromJune to November, with indexes almost always lower than $100 \mathrm{~mm}$ per month. The average annual rainfall is around 2,300 $\mathrm{mm}$. The relative air humidity in the region presents little fluctuation throughout the year, ranging between $81 \%$ and $89 \%$ (average values per year). The air temperature has mean values around $26{ }^{\circ} \mathrm{C}$ (VALENTE et al., 2014).

The seedlings were produced from seeds collected from native matrices of open pollination in the municipality of Anajás, PA in May 2004. This plants has aroused interest for its fruit production in the period considered as offseason in the state, i.e., in the January until June, which can generate material that may reduce the seasonality of production. Testing the progenies was startedin March 2005, using a randomized blockdesign, with 30 treatments (progenies), three replicates and five plants per plot withspacing of $6 \mathrm{~m} \times 4 \mathrm{~m}$, plus a plant 
line outside the experiment. The evaluated characteristics between the years of 2009 and 2012 were total weight of bunches (PTC), in grams; total weight of fruit (PTF), in grams; and average weight of 100 fruit (PCF). The different years with variations between relative humidity, total precipitation and average temperature were considered as the environments.

Table 1. Climatological data of the region of Tomé-Açu in four years of evaluations in 30 assai palm progenies. Anajás, PA.

\begin{tabular}{ccccc}
\hline & 2009 & 2010 & 2011 & 2012 \\
\hline Relative Humidity (\%) & 80,0 & 80,0 & 83,0 & 79,0 \\
Total Precipitation $\left(\mathrm{mm} . \mathrm{ano}^{-1}\right)$ & 2813,2 & 2226,8 & 3095,0 & 1794,8 \\
Average Temperature $\left({ }^{\circ} \mathrm{C}\right)$ & 26,1 & 26,5 & 26,0 & 26,2 \\
\hline
\end{tabular}

Source: Executive Comission of the Plan for the Farming of Cocoa - CEPLAC (2020).

Using the plants average of the plot, an analysis of variance was used to verify the existence of statistically significant differences among progenies with different characteristics. The statistical procedure adopted was proposed by Cruz et al., (2014).The statistical model was: $Y_{i j}=m+G_{i}+R_{j}+e_{i j}$; where $Y_{i j}$ is the mean phenotypic value of $Y$ measured in the genetic material $\mathrm{i}$, at cut $\mathrm{j} ; \mathrm{m}$ is the general average of the characteristic under study; $G_{i}$ is the effect of the $i$-th progeny, random effect; $R_{j}$ is the effect of the $j$-th repetition; $\mathrm{e}_{\mathrm{ij}}$ is the average error associated with observation $\mathrm{Y}_{\mathrm{ij}}$, random effect.

The method called GGE biplot was employed, which considers the effect of the genotype and the GxE interaction (YAN et al., 2000). In this method, only calculations of the main effect of genotype and of the GxE are important and considered concomitantly; the main effect of the environment is not relevant. The GGE biplot model does not separate G from GxE but keeps them together in two multiplicative terms, according to the following equation: $Y_{i j}-\bar{y}_{j}=y_{1} \varepsilon_{i 1} \rho_{j 1}+y_{2} \varepsilon_{i 2} \rho_{j 2}+\varepsilon_{i j}$ where $Y_{i j}$ is the average yield of the $i$-th population in the jth environment; $\bar{y}_{j}$ is the average of the populations in the environment $j ; y_{1} \varepsilon_{i 1} \rho_{j 1}$ is the first major component (IPCA1); $\mathrm{y}_{2} \varepsilon_{\mathrm{i} 2} \rho_{\mathrm{j} 2}$ is the second main component(IPCA2); $\mathrm{y}_{1}$ and $\mathrm{y}_{2}$ are eigenvalues associated with the IPCA1 and IPCA2, respectively; $\varepsilon_{\mathrm{i} 1}$ and $\varepsilon_{\mathrm{i} 2}$ are scores of the first and second major components, respectively, of the $\mathrm{i}$-th population; $\rho_{\mathrm{j} 1}$ and $\rho_{\mathrm{j} 2}$ are scores of the first and second main components, respectively, for the $\mathrm{j}$-th environment; $\varepsilon_{\mathrm{ij}}$ is the model error associated with the $\mathrm{i}$-th population and the $\mathrm{j}$-th environment (YAN; KANG, 2003).

The "relation of information (IR)" proposed by Yan and Tinker (2006) to evaluate the suitability of a biplot to display the patterns of a table of double entry was also calculated for each PC, which is the proportion of total variation explained by each PC multiplied by $\mathrm{k}$. The interpretation that must be adopted is a PC with IR $\geq 1$ contains standards (associations between environments), and a PC with IR $<1$ does not contain any standard or information. The biplot of dimension 2 accurately represents the patterns in the data if only the first two PCs have an IR $\geq 1$. 
The procedures of analysis of variance were performed with the statistical software Genes (CRUZ, 2016), and the R statistical program (R Core Team, 2016) was used for the analysis of the GGE biplot employing the GGEBiplotGUI package (BERNAL; VILLARDON, 2014).

\section{RESULTS AND DISCUSSION}

There were no differences among progenies $(\mathrm{G})$ by $\mathrm{F}$ test in the evaluated traits (Table 2), indicating that it is not possible to distinguish between the different progenies in this group of plants and with the environmental conditions imposed. The reason for this may be attributed to the procedure adopted during collection from its natural habitat, discarding the plants with the worst visual performance and subjectively harvesting the fruit with better performance from palms. This is similar to the results observed by Galate et al., (2014) for the characteristic PTC and discordant with what was observed by Oliveira and Fernandes (2001) for PTC and PTF, in which the plants evaluated had differentiation.

Table 2. Summary of analysis of variance for three characteristics ${ }^{\mathrm{a}}$ in 30 progenies of assai palm in four years. Anajás, PA.

\begin{tabular}{lrccc}
\hline \multicolumn{1}{c}{ FV } & GL & PTC & PTF & PCF \\
\hline Repetition & 2 & 360447629,99 & 110310102,29 & 111,20 \\
Progenies (G) & 29 & $153418709,32^{\text {ns }}$ & $75162813,75^{\text {ns }}$ & $553,55^{\text {ns }}$ \\
Years (A) & 3 & $7784830599,94^{\text {ns }}$ & $5134789466,24^{\text {ns }}$ & $1753,91^{\text {ns }}$ \\
Gx E & 87 & $44090616,17^{* *}$ & $20666719,53^{* *}$ & $18,69^{* *}$ \\
Error & 238 & 54287392,32 & 29198481,92 & 93,08 \\
\hline Total & 359 & & & \\
\hline Mean & \multicolumn{5}{c}{21751,63} & 140,15 \\
CV\% & & 25378,74 & 24,84 & 6,88 \\
\hline
\end{tabular}

a PTC: total weight of bunches, in grams; PTF: total weight of fruit, in grams; and PCF: average weight of 100 fruit. ns (not significant); * and ** (significance at 5 and $1 \%$ of the probability, respectively, by $\mathrm{F}$ test).

Between the years of evaluation (A) there were also no significant differences, indicating that in conditions of that experiment, the non-controllable factors alone did not contribute to the variability among the progenies in intensity. This could interfere in the values of the characteristics studied among the various crops, which may demonstrate apparent environmental stability, a very rare occurrence (CRUZ et al., 2014).

In contrast to the absence of detecting an effect of genotype and year, the GxE interaction was significant in all the characteristics evaluated. In this way, the genotypes interacted differently with the environmental conditions of each year, making it important to utilize the GGE biplot analysis. Important to note that phenotypically there is no way to visualize or distinguish the different progenies, as well as the effect of years. However, the interaction between $G$ and $A$ clearly shows that progenies respond differently to environmental stimuli, not having uniform behavior. This is important because it demonstrates that there is a differential response from progenies to environmental differences, indicating the need for adaptability and stability studies. 
Considering the relationship of information (IR) of the four main components (Table 3), only the first PC contains a pattern, being above the unit in IR1 and IR2 but below in PTC and PCF; for PTF, the first axis was also above the unit, while the second was not-despite being slightly below the unit, it may contain some independent information. Thus on the basis of IR, the GGE biplot can considered sufficient to represent the patterns of data.

The GGE biplot structures for each characteristic are shown in the Figures 1-3. On the abscissa of the biplot are scores of PC1 and on the ordinate axis are scores of PC2, of genotypes and environments. In the calculation of the cumulative percentage by the first two axes, the value was greater than $80 \%$ in the studied characteristics, which characterizes high reliability in the explanation of total variation of the performance of the progeny, added to the interaction with the environment $(\mathrm{G}+\mathrm{GxE})$. Apart from that the obtained values were lower for PTC and PTF, possibly due to the eminently allogamous crossing system of the species associated with the aspect of the process of domestication in the initial stage, there was no selection for stability, which means the progenies still suffer a great influence of environmental factors. The percentage obtained (above $89 \%$ ) for PCF was similar in comparison with other fruit: the production of fresh fruit of peppers (ABU et al., 2011); the average weight per fruit and number of fruit per melon plant (DEHGHANI et al., 2012); the number of kernels, yield and weight of kernels of cashew (ALIYU et al., 2014); and productivity in cassava genotypes (PEPRAH et al., 2016).

Table 3. Singular value, explained proportion and information relation (IR) of the four main components (PCs) for total fruit weight (PTF), weight of 100 fruit (PCF) and total weight of bunches (PTC) in progenies from assai.

\begin{tabular}{clrrrr}
\hline \multirow{2}{*}{ Characteristic } & Parameter & \multicolumn{4}{c}{ Main component } \\
\cline { 3 - 6 } & & \multicolumn{1}{c}{ PC1 } & \multicolumn{1}{c}{ PC2 } & PC3 & \multicolumn{1}{c}{ PC4 } \\
\hline \multirow{2}{*}{ PTC } & Singular Value & 42376.78 & 22802.70 & 18733.44 & 9745.71 \\
& Explained proportion(\%) & 65.03 & 18.83 & 12.71 & 3.43 \\
& IR & 2.60 & 0.75 & 0.51 & 0.14 \\
\hline \multirow{2}{*}{ PTF } & Singular Value & 28475.87 & 17440.16 & 12445.66 & 7481.97 \\
& Explained proportion(\%) & 61.16 & 22.94 & 11.68 & 4.22 \\
& IR & 2.45 & 0.92 & 0.47 & 0.17 \\
\hline PCF & Singular Value & 73.50 & 15.64 & 13.34 & 8.23 \\
& Explained proportion(\%) & 91.68 & 4.15 & 3.02 & 1.15 \\
& IR & 3.67 & 0.17 & 0.12 & 0.05 \\
\hline
\end{tabular}

Source: Own authorship.

Seeking to group the progenies and show how many and which ones behaved as the best and in which environments was structured the Figure 1 ("which-won-where"). This has importance for studying the possible formation of mega-environments in a region. In the figure, the progenies (genotypes) plotted on the vertices of the polygon for each sector are those with the best performance for the respective environments that were also included within this sector. The 30 evaluated progenies are identified from G1 to G30 and the four environments from A1 to A4, respectively from years 2009 to 2012. 

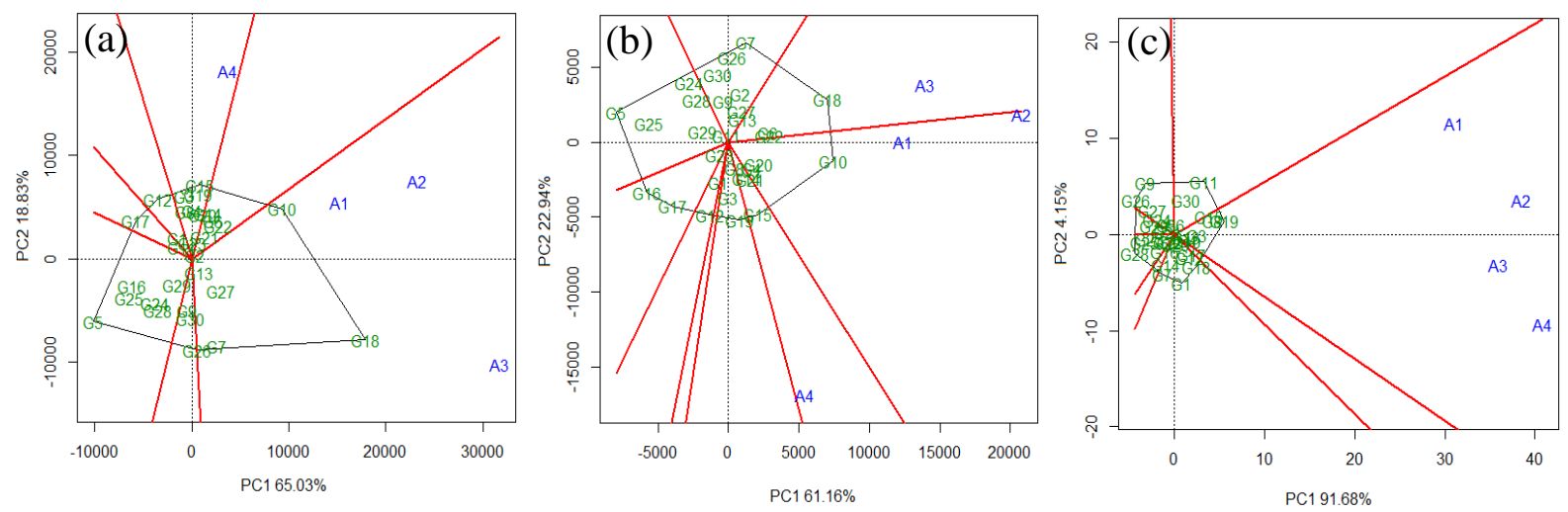

Figure 1. GGE biplot ("Which-won-where") for the data from the characteristics total weight of bunches (a), total fruit weight (b), and weight of 100 fruit (c) in assai progenies; this shows which progenies presented better performance in which environments.

Source: Own authorship.

The progenies that are plotted on the vertices of the polygon, for the characteristic PTC, were G5, G17, G12, G15, G10, G18 and G26. The four environments were separated to form two groups by lines that left from the biplot origin, with the first group (i) containing the environments A1, A2 and A3 and the second (ii) containing A4. This formation of only two groups suggests the existence of only two mega-environments. For PTF, the following progenies were plotted in the vertices of the polygon: G5, G7, G18, G10, G15, G19, G17 and G16. The four environments were divided by lines into three groups by lines that left from the origin of the biplot, forming three groups: (i) containing A3, A1; (ii) containing environment A2; and (iii) containing A4. This suggests that there are three mega-environments. For PCF, the progenies located at the vertices of the polygon were G1, G7, G28, G26, G9, G11, G19 and G18 and the four environments comprised one group, i.e., only one mega-environment, by lines that left from the origin of the biplot.

The uneven division of progenies and the different number of mega-environments formed for each characteristic is different from previous work: in pepper plants over three years by Abu et al. (2011); for fruit production of peach over three years (CITADIN et al., 2014); in the number of almonds per plant, productivity and weight of almonds in cashew trees (ALIYU et al., 2014), where there was equitable distribution of progenies in the megaenvironments, with the vertices (progenies) of the polygon near environments in this three cited examples. In the present study, the results also showed the presence of progenies that do not fit into any mega-environment. In strawberry productivity, there was a distinct behavior in which each site composed a mega-environment (COSTA et al., 2016); this also occurred in cassava (PEPRAH et al., 2016). This evidence indicates that the formation of the number of mega-environments is dependent on the genetic material and the characteristics evaluated.

The progenies G10 and G18 form the vertices of the sector in which the environments A1, A2 and A3 are located; therefore, these represent the best total weight of bunch (PTC) and total weight of fruit (PTF) in these environments, with G10 being closer to A1 and A2, and G18 to A3; for the environment A4, the progeny G15 had the best performance in these characteristics (Figure 1a and b). For the average weight of 100 fruit (PCF), progeny G19 forms the vertex of the sector where environments A1, A3 and A4 are; therefore, this progeny 
had the best performance associated with these environments (Figure 1c). The superior progenies in the environments were similar in PTC and PTF with emphasis onG10 and G18, and those that stood out at PCF were different to PTC and PTF.

Progenies for the characteristic PTC, identified as G5, G17, G12 and G26, resided in sectors defined by the vertices of the polygon that did not have environment in their proximity, meaning that these progenies were not higher in any one environment (Figure 1a). For PTF, the progenies not associated with any one environment were G5, G7, G19, G17 and G16 and in PCF they were G1, G7, G28, G26, G9, G11 and G18; these progenies had poor performance in all environments. It can be observed that G5, G7, G16, G17 and G26 showed a low performance in at least two of the evaluated characteristics. In addition to these low performing progenies, it should be noted that there were progenies with high adaptability to specific environments, but there were also progenies of intermediate performance and a majority that had no adaptability specific to any environment, mainly for PCF. In relation to these two observed behaviors, the presence of stability, adaptability to specific environments or periods, and also those without stability or adaptability, was similar to that found in studies involving other species, such as pepper (ABU et al., 2011), cashew (ALIYU et al., 2014), peach (CITADIN et al., 2014), strawberry (COSTA et al., 2016) and cassava (PEPRAH et al., 2016).

Although ANAVA (Table 2) was not sensitive enough to distinguish the progenies, the GGE Biplot (Figure 1a-c) allows to verify the existence of differentiated behavior of some progenies, highlighted in this discussion. This it can also be noted between the different years to PTC and PTF characteristics, where those environments (years) that are inserted within the same mega-environment resemble each other. The exception obtained for PCF shows that seed weight is little influenced by environmental differences.

In genetic improvement, the researcher idealizes a plant or genotype perfect for any environment, calling it an "ideotype". The ideotype represents the perfect result, because it presents a high average performance and high stability in different mega-environments. From this concept the researcher must have the tools to identify the genotype(s) that resemble(s) an ideotype, and the GGE biplot "Average versus Stability" is an effective tool for approaching this goal (YAN et al., 2007; YAN, 2011).
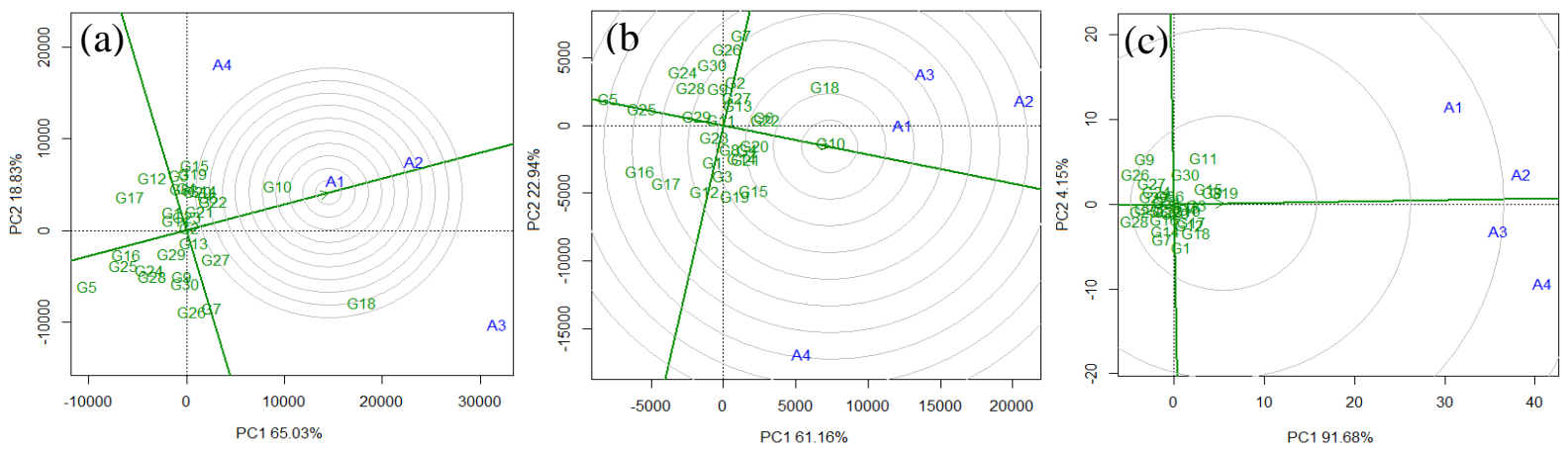

Figure 2. GGE biplot with average-environment axis (EAM) to classify the progenies in relation to the ideotype (in the center of the concentric circles) for the characteristics total weight of bunches (a), total weight of fruit (b), and weight of 100 fruit (c) in assai progenies. Source: Own authorship. 
A genotype, here denominated progeny, having only high stability is not sufficient to be select. Therefore, Figure 2a-c illustrate an important concept, allowing the association of stability with average performance; this is true if the genotype provides stability and also a high average performance in the characteristic that is being considered (YAN; TINKER, 2006; YAN, 2011). Based on these aspects, in the GGE biplot, the plotting of an ideotype is the concentric center is in the positive orientation in the EAM axis and has a length of vector longer than the vectors of genotypes, i.e., higher performance and better stability. Therefore, those genotypes that are located close to or over the center of the concentric circle are more desirable in comparison to those that are more distant.

This search for ideotype by the PTC characteristic revealed that progeny G10, was the closest to the ideal in this data set; with performance slightly below, there were progenies G14, G22 and G18 (Figure 2a) - in this sequence, the first two were superior to G18, as they presented better stability. For PTF, G10 was also the progeny that was located near the ideotype in this data set, followed by G18, G6 and G22 (Figure 2b); these last two were also interesting mainly because both presented better stability. For PCF, progeny G19 was the best in this data set, followed by progenies G8 and G15 (Figure 2c).In the opposite direction, the performances were lower for PTC (G17, G28, G24, G16, G25 and G5); for PTF, low performance was found for progenies G5, G25, G16, G17 and G24; and for PCF, low performing progenies were G26 and G28. These progenies should be avoided if the average characteristic associated with stability is to be increased. It is notable that GGE Biplot charts were able to identify progenies that perform better within the set of genetic material evaluated and that should certainly be carefully observed for future selection process.
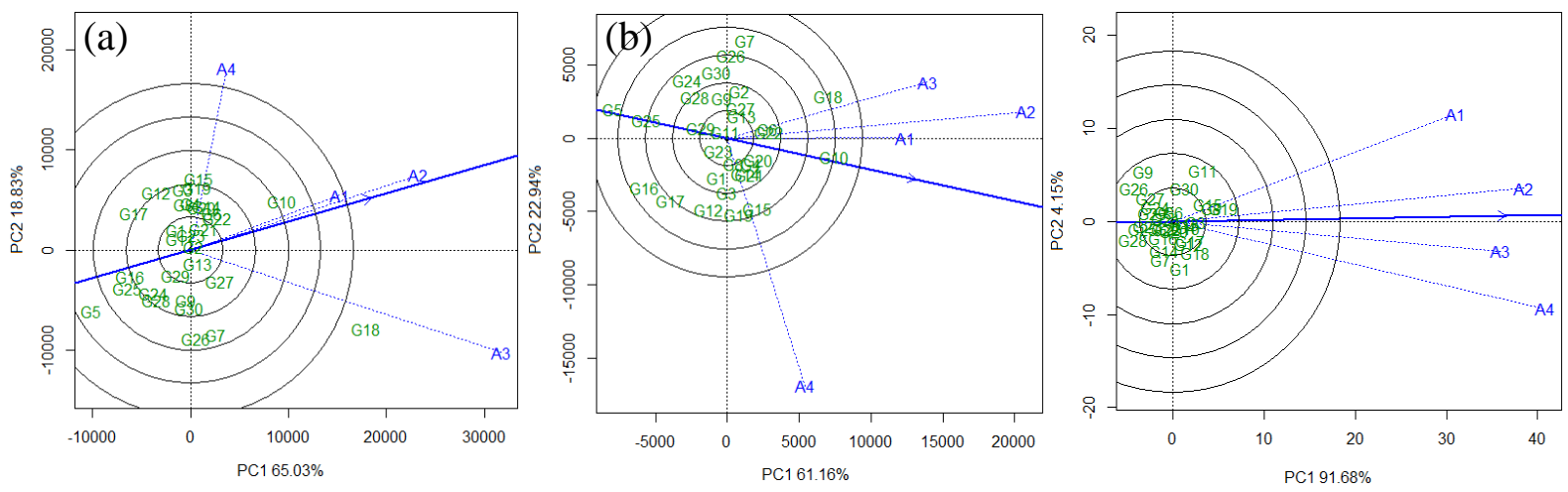

Figure 3. GGE biplot "discrimination and representativeness" to show the discrimination and representativeness of test environments in the characteristics total weight of bunches (a), total weight of fruit (b), and weight of 100 fruit (c) in assai progenies.

Source: Own authorship.

As can be seen in Figure 3, there are highly stable progenies (G2, G11, G13, G22 and G23), but unfortunately these did not present higher averages within the group of progenies for PTC. In the characteristic PCF, the majority of progenies were stable, but appropriate average values of PCF were not expressed, even though the relative performances of these were constant among the environments. However, these materials cannot be considered the ideotype. 
The fruit called "chumbinho" is preferred, i.e., reduced size and weight, due to the empirical citations of the professionals who work with the assai fruits to claim to have a higher yield of pulp. To obtain these characteristics, the most appropriate would be progenies G25, G26, G28 and G29, which are located on the limit of the outermost circle in Figure 2c, i.e., with lower weight, which is in opposition to the center that represents greater values for PCF.

The purpose of the test environment evaluation is to identify environments that can be used to select superior genotypes, here denominated progenies, effectively, representing a mega-environment; in other words, where it is possible to differentiate one genotype, allowing to select those with better averages. The selection of a test environment should provide greater discrimination of genotypes and representativeness. The visualization of the GGE biplot (Figure 3) has this purpose to be able to identify the best test environment(s).

The test environments are those that present longer vectors and can therefore be more differentiated in relation to the genotypes. When the environments have short vectors, they become less discriminating, which means that all the genotypes become similar; it is therefore recommended not to use these environments (HONGYU et al., 2015).

Environments A2 and A3, for the characteristic PTC, presented longer vectors in relation to the progenies, and were therefore more discriminating (Figure 3a). In addition, environments A1 and A4 can also be considered discriminating, except in relation to the progeny G18, which has no variation of behavior in different environments. For PTF, the environments A2, A3 and A4 (Figure 3b) were better able to differentiate the progenies and, for PCF, all environments presented much longer vectors in relation to all progenies (Figure $3 \mathrm{c}$ ), generating behavior of progenies that enabled differentiation. The longer vectors of environments in these three characteristics indicated that factors not associated with genetic control allow the differentiation of the behavior of each progeny of assai. Other species also showed similar modes of performance between environments and progenies, whose environments were more discriminating and only a genetic material exceeded the discrimination capacity of the environments as quoted by Peprah et al. (2016), who observed this in the productivity of cassava. However, for Aliyu et al. (2014), the number, weight and yield of cashew almonds per plant, only the environments had long vectors.

The discrimination and representativeness procedure of Figure 3 shows which factor (genotype or environmental) contributed most strongly to the observed overall behavior. In this case, environmental factors were mainly responsible for the differences in the variables associated with genetics of the progenies, showing that the genotypes were more similar to each other compared to the environmental variations that occurred between the different years.

A second need is to differentiate the environments that best represent the environment test, which can be seen in Figure 3. The interpretation of this superiority occurs in relation to possess a lower angle in the EAM (axis of environment-average). For PTC and PTF, the environments A1 and A2 and, for PCF, the environments A2 and A3 showed lower angles (Figure 4c). The other environments may be considered discriminating, but are not the most representative. They may be useful for the selection of progenies specifically adapted to 
certain mega-environments; or for the selection of unstable progenies if the test environment is a single mega-environment (Figure 3a-c). Thus, in the same way in cashew, the environments were more and less representative (ALIYU et al., 2014). Explaining better refers to the environment that best represents the overall average among all environments and can be considered as a replacement for all other environments (years).

\section{CONCLUSIONS}

For each characteristic, distinct progenies were highlighted according to stability and adaptability associated with the mean value for the characteristic evaluated. The results showed that the following progenies were close to the desired ideotype: G10 for PTC and PTF; G19 for large fruit or G25 for "chumbinho" fruits for PCF. There were also progenies that were inferior in the specific environments.

The progenies with higher average values for PTC and PTF showed low stability in the majority of cases, and, for PCF, most progenies were concentrated near the overall average. The GGE biplot plotted the progenies, allowing the choice of superior progenies and showing the inter-relationship of these with the environmental effects, where progenies with better average values and greater stability are more favorable.

The graphic analysis of the GGE biplot method showed that the environment that best discriminated the progenies was identified as A3 for PTC, A2 for PTF and A4 for PCF. For the representativeness of all environments, ie, the environment that represents of all environments average, the GGE biplot indicated the environments A1 and A2 for PTC, A1 for PTF and A2 for PCF.

\section{REFERENCES}

ABU, N. E.; UGURU, M. I.; OBI, I. U. Genotype by trait relations of yield and yield components in aromatic peppers (Capsicum annuum) based on GT biplot. Journal of Plant Breeding and Crop Science, Victoria Island, v. 3, n. 14, p.382-390, 2011.

ALIYU, O. M.; ADEIGBE, O. O.; LAWAL, O. O. Phenotypic stability analysis of yield components in Cashew (Anacardium occidentale L.) using additive main effect and multiplicative interaction (AMMI) and GGE biplot analyses. Plant Breeding Biotechnology, Gwonseon-gu, v. 2, n. 4, p.354-369, 2014.

BERNAL, E. F.; VILLARDON, P. G. GGEBiplotGUI: interactive GGE biplots in R. 2014. Disponível em: https://cran.r-project.org/web/packages/GGEBiplotGUI/index.html. Acesso em: 09 jan. 2020.

BRASIL. SUPERINTENDÊNCIA DO DESENVOLVIMENTO DA AMAZÔNIA. Projeto de Hidrologia e Climatologia da Amazônia. Atlas Climatológico da Amazônia brasileira. Belém: SUDAM, 1984. 125 p.

COMISSÃO EXECUTIVA DE PLANEJAMENTO DA LAVOURA CACAUEIRA CEPLAC. Dados Agrometeorológicos. Disponível em: http://www.ceplacpa.gov.br/site/wp- 
content/uploads/2010/04/Dados\%20climatologicos\%20Tome_Assu\%20.pdf. Acesso em: 10 jan. 2020.

CITADIN, I.; SCARIOTTO, S.; SACHET, M. R.; ROSA, F. J.; RASEIRA, M. C. B.; WAGNER JÚNIOR, A. Adaptability and stability of fruit set and production of peach trees in a subtropical climate. Scientia Agricola, Piracicaba, v. 71, n. 2, p.133-138, 2014.

COSTA, A. F.; TEODORO, P. E.; BHERING, L. L.; LEAL, N. R.; TARDIN, F. D.; DAHER, R. F. Biplot analysis of strawberry genotypes recommended for the State of Espírito Santo. Genetics and Molecular Research, Ribeirão Preto, v. 15, n. 3, p.1-9, 2016.

CRUZ, C. D. Genes Software: extended and integrated with the R, Matlab and Selegen. Acta Scientiarum, Maringá, v. 38, n. 4, p.547-552, 2016.

CRUZ, C. D.; CARNEIRO, P. C. S.; REGAZZI, A. J. Modelos biométricos aplicados ao melhoramento genético. 3. ed. Viçosa: UFV, 2014. 668 p.

DEHGHANI, H.; FEYZIAN, E.; JALALI, M.; REZAI, A.; DANE, F. Use of GGE biplot methodology for genetic analysis of yield and related traits in melon (Cucumis melo L.). Canadian Journal of Plant Science, Ottawa, v. 92, n. 1, p.77-85, 2012.

FARIAS NETO, J. T.; YOKOMIZO, G. K. I.; OLIVEIRA, M. S. P.; HONGYU, K. GGE Biplot para estabilidade e adaptabilidade em progênies de açaizeiro de Anajás, PA. Revista Agro@mbiente On-line, Boa Vista, v. 12, n. 1, p.409-417, 2018.

GAUCH, H. G.; PIEPHO, H. P.; ANNICCHIARICO, P. Statistical analysis of yield trials by AMMI and GGE: Further considerations. Crop Science, Madison, v. 48, n. 3, p.866-889, 2008.

GOMES JUNIOR, R. A.; GURGEL, F. L.; PEIXOTO, L. A.; BHERING, L. L.; CUNHA, R. N. V.; LOPES, R.; PINA, A. J. A.; VEIGA, A. S. Evaluation of interspecific hybrids of palm oil reveals great genetic variability and potential selection gain. Industrial Crops and Products, Amsterdam, v. 52, n. 1, p.512-518, 2014.

HASSANPANAH, D. Analysis of GxE interaction by using the additive main effects and multiplicative interaction in potato cultivars. International Journal of Plant Breeding and Genetics, New York, v. 4, n. 1, p.23-29, 2010.

HONGYU, K.; SILVA, F. L.; OLIVEIRA, A. C. S.; SARTI, D. A.; ARAUJO, L. B.; DIAS, C. T. S. Comparação entre os modelos AMMI e GGE Biplot para os dados de ensaios multiambientais. Revista Brasileira de Biomassa, São Paulo, v. 33, n. 2, p.139-155, 2015.

INSTITUTO BRASILEIRO DE GEOGRAFIA E ESTATÍSTICA - IBGE. Produção da Extração Vegetal e da Silvicultura 2016. Rio de Janeiro: IBGE, 2013. v. 31, p.17-18.

MORETO, A. L.; NEUBERT, E. O.; PERUCH, L. A. M.; POLA, A. C.; LORENZI, E. F. P.; NUNES, E. C. Desempenho de genótipos de mandioca via metodologia de modelos mistos em Santa Catarina, Brasil. Revista de Ciências Agrárias, Lisboa, v. 40, n. 4, p.160-169, 2017. 
NOGUEIRA, A. K. M.; SANTANA, A. C. Benefícios socioeconômicos da adoção de novas tecnologias no cultivo do açaí no Estado do Pará. Revista Ceres, Viçosa, v. 63, n. 1, p.17, 2016.

NOGUEIRA, A. K. M.; SANTANA, A. C.; GARCIA, W. S. A dinâmica do mercado de açaí fruto no Estado do Pará: de 1994 a 2009. Revista Ceres, Viçosa, v. 60, n. 3, p.324-331, 2013.

OLIVEIRA, M. S. P.; FERNANDES, G. L. C. Repetibilidade de caracteres do cacho de açaizeiro nas condições de Belém, PA. Revista Brasileira de Fruticultura, Jaboticabal, v. 23, n. 3, p.613-616, 2001.

PEPRAH, B. B.; AGYEMAN, A.; PARKES, E.; KWADWO, O.; ISSAC, A. K.; EMMANUEL, O.; LABUSCHAGNE, M. T. Stability, agronomic performance and genetic variability of 10 cassava genotypes in Ghana. Journal of Plant Breeding and Crop Science, Victoria Island, v. 8, n. 9, p.157-167, 2016.

R CORE TEAM. R: A language and environment for statistical computing. R Foundation for Statistical Computing, Vienna, Austria. 2016. Disponível em: http://www.R-project.org/. Acesso em: 8 mar. 2019.

TEODORO, P. E.; NASCIMENTO, M.; TORRES, F. E.; BARROSO, L. M. A; SAGRILO, E. Perspectiva bayesiana na seleção de genótipos de feijão-caupi em ensaios de valor de cultivo e uso. Pesquisa Agropecuária Brasileira, Brasília, v. 50, n. 10, p.878-885, 2015.

VALENTE, M. A.; WATRIN, O. S; CASTRO, A. R. C. Mapeamento detalhado dos solos da fazenda experimental da Embrapa Amazônia Oriental em Tomé-Açu, PA. Belém: Embrapa Amazônia Oriental, 2014. 33 p. (Embrapa Amazônia Oriental. Documentos, 405).

YAN, W. Singular-value partition for biplot analysis of multi-environment trial data. Agronomy Journal, Madison, v. 94, n. 5, p.990-996, 2002.

YAN, W.; KANG, M. S. GGE Biplot Analysis: A Graphical Tool for Breeders, Geneticists, and Agronomists. Boca Raton: CRC, 2003. 271 p.

YAN, W. GGE Biplot vs. AMMI Graphs for Genotype-by-Environment Data Analysis. Journal of the India Society of Agricultural Statistics, New Delhi, v. 65, n. 2, p.181-193, 2011.

YAN, W.; HUNT, L. A.; SHENG, Q.; SZLAVNICS, Z. Cultivar evaluation and megaenvironment investigation based on GGE biplot. Crop Science, Madison, v. 40, n. 3, p.597-605, 2000.

YAN, W.; KANG, M. S.; MA, B.; WOODS, S.; CORNELIUS, P. L. GGE biplot vs. AMMI analysis of genotype-by-environment data. Crop Science, Madison, v. 47, n. 2, p.643-653, 2007.

YAN, W; TINKER, A. Biplot analysis of multi environment trial data: principles and applications. Canadian Journal of Plant Science, Ottawa, v. 86, n. 3, p.623-645, 2006.

YOKOMIZO, G. K. I.; FARIAS NETO, J. T.; OLIVEIRA, M. S. P. Ganho esperado na seleção de progênies de polinização aberta de Euterpe oleracea para produção de frutos. Scientia Forestalis, Piracicaba, v. 44, n. 109, p.241-248, $2016 \mathrm{a}$. 
YOKOMIZO, G. K. I.; MOCHIUTTI, S.; QUEIROZ, J. A. L.; SANTOS, G. R.; FURTADO, R. G.; BRANDÃO, A. P.; COLARES, I. B. Estimativas de parâmetros genéticos para caracteres de frutos em açaizeiros no Amapá. Ciência Florestal, Santa Maria, v. 26, n. 3, p.985-993, 2016b. 